\title{
Analysis of Kodaly's Ideals of Music Education
}

\author{
HAN Jinshan \\ Base of Training, Army Logistics University of PLA, Lecturer, \\ Xiangbei, Xiangyang City, Hubei Province, China \\ 286786800@qq.com
}

\begin{abstract}
Keywords: View of mass music education, View of national music education, music teaching methodology, Chorus teaching.
\end{abstract}

\begin{abstract}
Kodaly Zoltan was a famous composer, a national musician and a music educator in Hungary. Kodaly's ideals of music education were one of the most influential ideals of the music education in the world and spread in many countries. The view of mass music education, the view of national music education, the practical music teaching methodology and the praising highly of chorus teaching are one of his ideals of music education. Kodaly's ideals of music education are rich in the affinity to the people and his life was to do his utmost to portray and promote the artistic accomplishment of the nation.
\end{abstract}

\section{Introduction}

As a famous composer, a national musician and a music educator, Kodaly Zoltan was born in 1882 in Hungary. Based on researching the music teaching methodology all over the world, and combining the national conditions and the national music characteristic of Hungary, Kodaly formed his own ideals of music education during his music education career. In the first half of 20th century, his ideals of Music Education became the guiding ideology and the music teaching basis in Hungary. In 1964, the Kodaly Music Education Methodology, which named after his name, was popularized by ISME and IFMC in the member countries. And Kodaly's ideals of music education began to spread in the world and became one of the most influential ideals of the music education. The ideological system, and incidentally the founding background, the main viewpoints, the social values, and the inspiration of Kodaly's ideals of music education are the content discussed in this article.

\section{View of mass music education}

Leading the masses to the music is the core concept of Kodaly's view of mass music education. [1] He thought that the goal of the music education in Hungary was not only to train a small number of musicians, but to make the masses to gain music knowledge and become the concert audience who had talented music accomplishment. And the music was not the means of making a living by Hungarians, but a part of their lives. He emphasized that the music belonged to every people who should be accepted the music education. He said that sing to ourselves was valueless, it was better that two people sing together, thousands of people sing together and the singing became a great harmonious sound, then we could say that the whole world became more beautiful. [2]

Belonging to everybody, the music is the part of a person's civilization and the music education is the need of a whole man. [3] Those are Kodaly's conception of the relationship between music and man. As a musician and music educator, Kodaly stood at the height of the optimization of the whole national culture quality to understand the educational function of the music. Hoped to improve the quality of the citizens through the music education, Kodaly paid close attention to the children's and the teenagers' music education, the training of the children's artistic appeal and connoisseurship, the children's varied and colorful living created through the music. He deeply studied the students' emotional cultivation and aesthetic consciousness. During the children's music creation, Kodaly chose the popular ditty sang in mother tongue as the material of musical creation to pure nice, positive and healthy music into the children's heart. He wanted to develop the children's emotion, intelligence 
and personality with more and better music and to enrich their inner world. He considered music education in general school basis of forming the integrated personality of the children.

From 1950s, the government of Hungary stipulated that the music education in school must adopt the Kodaly Music Education Methodology and the children from nursery school to high school could accept good music education. Many Hungarian composers, cantors, singers, accomplished performers and musical educators accepted the education under the Kodaly Music Education Methodology. Kodaly's view of mass music education tells us that the overall level of a nation's music education is directly related to the quantity and quality of the musical specialized personnel. And born on the basis of the high level of common music education, the excellent musical specialized personnel and their music works will win a wide music stage and the broad masses of the audience.

\section{View of national music education}

One of Kodaly's outstanding characteristics ideal of music education is its national traits and his career roots in national music all along. Kodaly thought that the language and thinking of the national music had special meanings in training people's national consciousness and emotions. He said that the Hungarian classic music was only reflected in several thousang traditional melodies, which were now the intrinsic quality of Hungarian nation if we thonght that the national classic culture was the most perfect manifestation of the national spirit.Because of belonging to the whole people, as a wealth, these melodies not only had folk significance but also had national significance. If we were in pursuit of a component music culture, we must made them own by the whole people.[4]

The folk music is the people's spiritual sustenance and also the source of the composer's inspiration. Kodaly made a great contribution to the work of collectting, collating and studying the theory of folk music in Hungary. He once went allover the country to collect folk songs and collected 3,000 pieces of folk melodies. He thought that acceptting and maintaining the tradition and made them active parts of the lives of the people was the mission of the music education. How to accept and maintain the tradition, Kodaly assumed two ways. One was to guarantee the universality and durability of the folk music education from law and the content of the book by ways of mass music education because it was the shortest way to the folk songs through music education. [5] The other was that the producing and polishing of the music must be based on folk music. The vast amount of music works composed by Kodaly benefited from puting the composing technique of classic music into displaying Hungarain music. In addition, Kodaly's foresight and sagacity embodied the recognization of the long-term efficacy of the national music to the music education. He thought that the more songs agglutinating people's wisdom and emotion instilled into the young people's heart, the closer the young people would maintainthemselves with the nation, which meant the young people would recognize their motherland, have an intimate knowledge of the people, have ardent love for the magnificent culture of national music by learning folk songs and achive the aim of the patriotism education.

Kodaly's view of national music education tells us that under the situation of popular music floods the marketplace and national music is cold-shouldered, the outlet for inheriting and developing the national music lies in going firmly the way of national music education. It is the basis of founding a music educational system with national characteristics to increase the quantity, improve the quality and teaching level of the national music education book beginning with the elementary music education.

\section{Practical music teaching methodology}

The Kodaly Music Education Methodology is the liveliest, most active and most fruitful part of Kodaly's ideal system, and also the essence of Kodaly's teaching ideal. Kodaly founded a to-the-intuitive teaching philosophy. He pointed out that the method of teaching music and songs in school must let the students feel happy but not tormented. Don't let the children get in touch with the music from intellectual power or rational faculty, and also don't treat the music as a system of the 
algebraic symbols or a kind of a coded language imparted to the children which had nothing to do with the children. A way to the intuitive should be built. [6]

According to the guiding ideology above, in music teaching, the Kodaly Music Education Methodology changed the previous model of teaching in which the teaching sequence was arranged on the basis of the logic order of the music theoretical system, and arranged the order of the courses according to the normal children' capabilities formed during the children's mental and physical growth. Kodaly advocated that the emphasis of the children's music education should be put on perception but not rational faculty. The music was the art of sound. Belonging to the senior sense organs, the sense of hearing which was the foundation of feeling music became divided earlier than other sensory organs. To give great attention to the golden period of the children's fast development sense of hearing was the crucial period of the children's growing up to being useful. So Kodaly attached great importance to the early music education and considered meticulous designing and compiling the children's music textbook the foundation engineering among the whole music education engineering.

On the guiding ideology of the teaching method reformation, Kodaly advocated to rationally draw on, transform and constitute the outstanding achievement of other countries' music teaching methods to make them the teaching framework with Hungarian characteristics. The four effective teaching methods of the Kodaly Music Education Methodology— the tonic sol-fa method, the gestures roll-call method, the rhythm duration syllable pronunciation method and the numbered musical notation of rhythm letter method are the best examples. These methods are based on drawing on the English Tonic sol-fa method, the Colvin gestures roll-call method, the France rhythm duration syllable pronunciation method and the byte musical alphabet. Giving priority to perception, putting the emphasis of teaching on the music practice and dispersing the difficult point of teaching in practice, the Kodaly Music Education Methodology is of sound theoretical basis and feasible applicability and ensure the succeed of the music teaching reform in Hungry.

\section{Praise highly of chorus teaching}

It is the major part of Kodaly's music education thought to praise highly of the chorus and the chorus teaching occupies an important place in the Kodaly Music Education Methodology. The chorus is the art that the music images are portrayed by sound without extra expenses. So it is a music education form which is economic, simple and spread easily. Starting from kindergarten, all the Hungarian children accepted the two-part-sightsinging-training and then the training passed to the regular chorus training. Among the numerous music teaching forms, Kodaly chose the chorus as main teaching form not only because he had a partiality for it but also that it met the needs of the Hungarian conditions of the nation and people at his time.

Kodaly has some original viewpoints on the efficacy of the chorus teaching. First of all, He thought that the chorus teaching was an education not to be ignored to the teenagers' training of the collectivism spirit and the spirit of the national unity. He said that no matter how good education the parents gave their children, even if they were the most meticulous and richest, they could not gave their children the education of the collectivism spirit. He thought to himself that there was nothing better indicated the social unity than the chorus and the united people could do the things that one single person could not do even how talented he or she was. In this connection, everyone' work was of the same importance and one person's mistake would destroy all. [7]

Secondly, it is another major standpoint of the Kodaly Music Education Methodology that the students' multi-voice harmony sense of hearing can grow through the chorus training. The music education practice in Hungary in half a century proved the superiority of the training of the students' multi-voice harmony sense of hearing. First, the art practice of using directly their own vocal organs must visually experience the various music elements to improve at the same pace the music capacity of feeling and expression. And then, the teaching method of practicing the ear-training is more lively and depictive, and more easy to arouse the students' interest of studying than that of practicing the ear-training by listening to the piano played by the teacher. 


\section{Conclusion}

As an integrated and systematic theoretical system of music education, Kodaly's ideals of music education, rich in the affinity to the people, are now accepted and becoming the valuable wealth serving for the people all over the world. He understood the truth that the music derived from the people and should be dedicated to the people and he returned the music to the people by means of the music education. [8]Kodaly's ideals of music education are his view of art expressed in the musical creation and the achievements in making unremitting efforts to study Hungarian folk music. Kodaly's life was not to seek the original creation in the art field, but to do his utmost to portray and promote the artistic accomplishment of the nation. Kodaly succeeded in the final analysis just because he was a faithful son of the Hungarians.

\section{References}

[1] Seabó Helgn, The Kodaly’s concept of music education, I Boosey\& Hawkes press, pp. 17, 1969.

[2] The selected writing of Kodaly Zoltan, Boosey\& Hawkes press, pp. 125-126, 1974.

[3] Kodaly Zoltan, In retrospect, Zenemikiodó press, pp. 196, 1964.

[4] YANG Limei, The ideals and practice of Kodaly' music education, Renmin university of China press, pp. 49-50, 1994.

[5] YANG Limei, The ideals of Kodaly' music education and the music education in Hungary, Shanghai education press, pp. 137, 2000.

[6] QI yi, ZHANG Wenchuan, The art of music education, The people's music press, pp. 126, 2002.

[7] Bennett Ramo, The philosophy of the music education, The people's music press, pp. 214, 1970.

[8] LIU Chenhua, The cultural interpretation of Chinese music education, Shanghai music press, pp. $189,2002$. 